\section{Global Rates of Marine Sulfate Reduction and Implications for Sub-Sea-Floor Metabolic Activities}

\author{
Marshall W. Bowles, ${ }^{1 *} †$ José M. Mogollón, ${ }^{1,2,3} \dagger$ Sabine Kasten, ${ }^{1,2}$ Matthias \\ Zabel, ${ }^{1}$ Kai-Uwe Hinrichs ${ }^{1}$
}

${ }^{1}$ MARUM Center for Marine Environmental Sciences, University of Bremen, Bremen, Germany. ${ }^{2}$ Alfred Wegener Institute Helmholtz Centre for Polar and Marine Research, Bremerhaven, Germany. ${ }^{3}$ Department of Earth Sciences-Geochemistry, Faculty of Geosciences, Utrecht University, Netherlands.

*Corresponding author. E-mail: bowlesmw@uni-bremen.de

†These authors contributed equally to this work.

Sulfate reduction is a globally important yet poorly quantified redox process in marine sediments. We developed an artificial neural network trained with 199 sulfate profiles, constrained with geomorphological and geochemical maps to estimate global sulfate reduction rate distributions. Globally, $11.3 \mathrm{Tmol}$ sulfate are reduced yearly, $\sim 15 \%$ of previous estimates, accounting for the oxidation of $12-29 \%$ of the organic carbon flux to the sea floor. Combined with global cell distributions in marine sediments, these results indicate a strong contrast in sub-sea-floor prokaryote habitats: in continental margins global cell numbers in sulfate-depleted sediment exceed those in the overlying sulfate-bearing sediment by an order of magnitude, whereas in the abyss most life occurs in oxic and/or sulfate-reducing sediments.

Sulfate reduction is a ubiquitous microbial process in oceanic sediments and an important pathway for carbon oxidation and redox cycling. Nevertheless, the currently estimated global sulfate reduction rate (SRR) of, 75 Tmol sulfate $\mathrm{y}^{-1}(1)$ is based on coarse spatial averaging and is not consistent with the up-to-date assessment of the global organic matter flux to marine sediments (2) of 79 to $192 \mathrm{Tmol} \mathrm{C} \mathrm{y}^{-1}(3,4)$. Net sulfate reduction follows a 2-C-to-1-S stoichiometric ratio [ $\mathrm{C}_{6} \mathrm{H}_{12} \mathrm{O}_{6}+3 \mathrm{SO}_{4}^{2-} \rightarrow 3 \mathrm{~S}^{2-}+6 \mathrm{CO}_{2}+6 \mathrm{H}_{2} \mathrm{O}$, e.g., (5)].

Therefore, the current estimates for the rate of subsurface sulfate reduction and for the organic carbon flux to the sediment suggest that either insufficient organic carbon reaches the sediment to account for sulfate reduction or that most $(78 \%)$ organic matter is channeled toward sulfate reduction. Nevertheless, the organic carbon reaching the sediment must also foment other prominent redox reactions such as carbon respiration $(4,6)$, and moreover, a sizable portion of sedimentary organic matter successfully survives early diagenesis and is buried (7). This discrepancy in global geochemical cycles gives impetus for an amended global view on sulfate reduction which can be merged with recently revised global prokaryotic abundances to properly assess the activity of sulfate reducing microorganisms at a global scale $(5,8-11)$.

We used currently available sulfate concentration profiles from multiple scientific ocean drilling programs (12) to estimate global net SRRs (Fig. 1A). These profiles were best described by assuming that sulfate concentrations exponentially decrease with depth. A total of 199 sulfate profiles (Fig. 1B) with a mean error square value $<4 \mathrm{mM}^{2}$ based on a least-squares regression were selected for the global SRR analysis. We then used depth-decay constants $(b)$ extracted from these profiles to train an artificial neural network (ANN) using high-resolution (1x1 degree) satellite observations and water column chemistry maps (e.g., surface water chlorophyll A, particulate organic carbon, and bottom water $\left.\mathrm{O}_{2}\right)(13,14)$ (table S1) (12).

The ANN predicts depth-decay constants ranging 16 orders of magnitude from $5.8 \times 10^{-13}$ to $3.2 \times 10^{2} \mathrm{~m}^{-1}$ while depth-integrated SRRs calculated using a steady state diffusion, advection, and reaction function (eq. S8) (12) ranged from $5.8 \times 10^{-12}$ to $8.2 \mathrm{mmol}$ $\mathrm{cm}^{-2} \mathrm{y}^{-1}$. The highest SRRs were predicted in shelf environments and the lowest SRRs were calculated in the nutrient-poor oceanic gyres (Fig. 1A and Table 1). These general trends are corroborated by a previous prediction of global, depth-integrated SRRs derived from, and mainly reflecting, the distributions of primary productivity. They are furthermore consistent with observations in previous studies of global sulfate profiles from oceanic deep drilling programs (5), as well as global compilations of radiotracer gross SRR measurements (15). Although the ANN is trained and validated solely with deep sea drilling data (Fig. 1B) (12), it replicates exponential sulfate depth-decay coefficients from several published short cores $(<15 \mathrm{~m})$ (fig. S4) taken below the shelf break and captures deep-sea locations characterized by high regional rates of SR coupled to methane oxidation [e.g., $0.05-0.4 \mathrm{mmol}$ $\mathrm{cm}^{-2} \mathrm{y}^{-1}$ in the Arabian Sea (16)].

From an environment-specific perspective, the ANN predicts a fourth of the previously estimated, area-weighted depth-integrated SRR for shelf sites: $0.097 \mathrm{mmol} \mathrm{cm}^{-2} \mathrm{y}^{-1}$ (15) vs. $0.0247 \mathrm{mmol} \mathrm{cm}^{-2} \mathrm{y}^{-1}$ (Table 1). All average depth-integrated rates determined here are considerably lower than previously reported (15), but appear to agree better with regionally averaged sulfate penetration depths. For example, assuming the previous upper continental slope average areal rate of $7.4 \times 10^{-2}$ mmol cm $\mathrm{c}^{-2}$ (15), a tortuosity-corrected diffusion coefficient of 120 $\mathrm{cm}^{2} \mathrm{y}^{-1}$ and a porosity of 0.8 , the average sediment depth where sulfate depletes to $0.3 \mathrm{mM}$ in sediments would be only $35 \mathrm{~cm}$ or $1.74 \mathrm{~m}$ assuming a linear or an exponential profile, respectively. The calculations here yield an average depth integrated rate for the upper slope of $1.7 \times 10^{-2}$ $\mathrm{mmol} \mathrm{cm} \mathrm{y}^{-2}$. This rate would produce $0.3 \mathrm{mM}$ sulfate concentrations at a depth of $1.2 \mathrm{~m}$ or $20 \mathrm{~m}$ below sea floor (mbsf) for these same cases, respectively. The main reason for this difference is that the previously compiled global SRRs did not account for large sea-floor surface areas (e.g., $\sim 70 \%$ of the continental shelf) consisting of organic-poor relict sands (17), and thus were averaged with a bias toward high-activity, organic-rich sites $[\mathrm{cf} .(8,18)]$. This and other geochemical and depositional heterogeneities observed in coastal sediments may also explain some of the larger deviations between fitted and ANN-predicted $b$ val- 
ues for some shallow-water cores (Fig. 1B). For instance, order-ofmagnitude variations in SRRs have been estimated within a single muddy basin [e.g., within $3000 \mathrm{~km}^{2}$ in Arkona Basin (19)], and likewise for small gassy basins [e.g., $8 \mathrm{~km}^{2}$ in Aarhus Bay (20)].

The ANN-based global net SRR estimate (11.3 Tmol S y ${ }^{-1}$ ) (Table 1 ) is roughly $15 \%$ of previous estimates for gross SRR (1). Although calculating global net as opposed to gross SRR could explain this divergence, it is highly unlikely that gross SRRs account for more than $78 \%$ of the global organic carbon flux to the sea floor. In contrast, the 11.3 Tmol S y ${ }^{-1}$ predicted by the ANN is equivalent to $22.6 \mathrm{Tmol} \mathrm{C} \mathrm{y}^{-1}$ [assuming a 2-C-to-1-S stoichiometry $(5,12)]$ or a more realistic $11-29 \%$ of the estimated global organic carbon flux to the sea floor.

This substantial diminution in global SRRs inherently affects previous conceptions of global microbial process distributions in sub-seafloor sediments. Subsurface microorganisms largely depend on harvesting energy from the organic matter reaching the sea floor. This amount is minor in comparison to the carbon supplied to seawater prokaryotes via photosynthesis (4.3 Pmol $\mathrm{C} \mathrm{y}^{-1}$ ) (21). In spite of this sharp contrast in carbon availability the marine subsurface total prokaryotic biomass is approximately equal to that of seawater $(8)$.

Coupling the ANN-derived global SRR maps to global sub-sea-floor biomass maps (8) allows for the calculation of potential cell-specific rates, which can further elucidate the activities of sulfate reducing microorganisms across various global sedimentary environments. These microorganisms thrive in anoxic surficial sediments where sulfate and labile organic substrates coincide. Within inner shelf sediments $(<50 \mathrm{~m}$ water depth), which typically receive the highest inputs of labile organic matter, area-weighted SRR averages (Fig. 2, A and B) exhibited the highest rates $\left(1.5 \mathrm{nmol} \mathrm{cm} \mathrm{d}^{-3}\right)$, leading to sub-micromolar sulfate concentrations by 6 mbsf. Furthermore, inner shelf sediments comprise the highest prokaryotic cell abundances (Fig. 2C) and cell specific rates (Fig. 2D) around $0.1 \mathrm{fmol} \mathrm{cell}^{-1} \mathrm{~d}^{-1}$. These data are in strong contrast to deep-water environments, which receive considerably less organic carbon. Peak SRRs in abyss sediments ( $>3500 \mathrm{~m}$ water depth) are a fraction of the shallow-water counterparts, at $0.03 \mathrm{pmol} \mathrm{cm}^{-3} \mathrm{~d}^{-1}$. Furthermore, cell abundances are in general lower, with the cell-specific rates reaching a maximum of $9 \times 10^{-4}$ fmol cell ${ }^{-1} \mathrm{~d}^{-1}$.

Simultaneous measurements of SRRs and sulfate reducing microorganism abundances are rare but the existing data are consistent with our model (22-26). The majority of these data exist for relatively shallowwater, high-productivity sites (e.g., Aarhus Bay), with surficial cellspecific SRRs around $0.1 \mathrm{fmol}$ cell $^{-1} \mathrm{~d}^{-1}$ and reaching $1.0 \times 10^{-3} \mathrm{fmol}$ cell $^{-1} \mathrm{~d}^{-1}$ by about $1 \mathrm{mbsf}(11)$. These data are within the range of our areal weighted average for $0.1 \mathrm{mbsf}$ of $0.1 \mathrm{fmol} \mathrm{cell}^{-1} \mathrm{~d}^{-1}(<50 \mathrm{~m}$ water depth, Fig. 2). In our modeled shallow-water environments (i.e., inner and outer shelves), high SRRs lead to peak cell-specific rate values near the sediment-water interface. These cell-specific rates taper quickly to zero as sulfate becomes exhausted. Our results show that peak values for the slope also occur near the sediment-water interface (with a slight increase with sediment depth) and gradually decrease as sulfate approaches zero. The abyss, however, does not reach a peak cell-specific rate within the top $80 \mathrm{mbsf}$, and values remain an order of magnitude lower than the peak values for the other environments. Notably, for the assumed fractions of sulfate reducers within the total microbial community (1 to 30\%), the general trends for of cell-specific SRR in different envi- ronments persist (Fig. 2D).

Results of the global survey show a distinct trend between environments in the continental margin and the abyss. The abyss (>3500 m water depth) is typically characterized by organic-poor sediments that allow for deep sulfate penetration. This prevalence of sulfate at great sedimentary depths indicates that most cells within the habitable deep sedimentary biosphere (down to 4000 mbsf or the specific basement depth) are found in either oxic or sulfate-reducing settings (Table 2). Nevertheless, within the other environments on the continental margins, sulfate is removed at comparatively shallow sediment depths $(<100 \mathrm{~m})$ (Table 2$)$. The sulfate-methane transition zone (SMTZ) is a distinct geochemical horizon that represents an important transition from sulfate reducing (above) to methanogenic sediments (below) $(1,19,20)$. Limited data from deep sea cores at these sites suggest that acetate and hydrogen can be abundant and thus serve as substrates for a vast methanogenic subsurface $(27-29)$.

Collectively, these observations indicate that, although the lack of reduced substrate limits sulfate reduction in deep-sea sediments, the continental margins harbor an expansive biosphere below the SMTZ where traditional, energy-rich electron acceptors are exhausted, and thus this fraction of the microbial biosphere is largely fermentative and methanogenic (Table 2 and figs. S5 and S6). Roughly estimating the SMTZ at the depth where sulfate depletion reaches $0.1 \mathrm{mM}$ sulfate, habitable sediments located below the SMTZ would comprise a total global subsurface volume of $10^{8} \mathrm{~km}^{3}$ (32\% of total), hosting approximately $50 \%$ of the sub-sea-floor biomass (12). However, $\sim 90 \%$ of cells in the subsurface at the continental margins $(<3500 \mathrm{~m}$ water depth) would be situated below the SMTZ (12).

\section{References and Notes}

1. B. B. Jørgensen, S. Kasten, "Sulfur cycling and methane oxidation," in Marine Geochemistry, M. Zabel, H. Schulz, Eds. (Springer Press, Berlin, 2006), pp. 271-309.

2. D. E. Canfield, Sulfate reduction in deep-sea sediments. Am. J. Sci. 291, 177188 (1991). Medline doi:10.2475/ajs.291.2.177

3. P. Regnier, P. Friedlingstein, P. Ciais, F. T. Mackenzie, N. Gruber, I. A. Janssens, G. G. Laruelle, R. Lauerwald, S. Luyssaert, A. J. Andersson, S. Arndt, C. Arnosti, A. V. Borges, A. W. Dale, A. Gallego-Sala, Y. Goddéris, N. Goossens, J. Hartmann, C. Heinze, T. Ilyina, F. Joos, D. E. LaRowe, J. Leifeld, F. J. R. Meysman, G. Munhoven, P. A. Raymond, R. Spahni, P. Suntharalingam, M. Thullner, Anthropogenic perturbation of the carbon fluxes from land to ocean. Nat. Geosci. 6, 597-607 (2013). doi:10.1038/ngeo1830

4. J. P. Dunne, J. L. Sarmiento, A. Gnanadesikan, A synthesis of global particle export from the surface ocean and cycling through the ocean interior and on the seafloor. Global Biogeochem. Cycles 21, GB4006 (2007). doi: 10.1029/2006GB002907

5. S. D'Hondt, S. Rutherford, A. J. Spivack, Metabolic activity of subsurface life in deep-sea sediments. Science 295, 2067-2070 (2002). Medline doi: $10.1126 /$ science. 1064878

6. H. E. Hartnett, R. G. Keil, J. I. Hedges, A. H. Devol, Influence of oxygen exposure time on organic carbon preservation in continental margin sediments. Nature 391, 572-575 (1998). doi:10.1038/35351

7. K. Wallmann, E. Pinero, E. Burwicz, M. Haeckel, C. Hensen, A. Dale, L. Ruepke, The global inventory of methane hydrate in marine sediments: A theoretical approach. Energies 5, 2449-2498 (2012). doi:10.3390/en5072449

8. J. Kallmeyer, R. Pockalny, R. R. Adhikari, D. C. Smith, S. D'Hondt, Global distribution of microbial abundance and biomass in subseafloor sediment. Proc. Natl. Acad. Sci. U.S.A. 109, 16213-16216 (2012). Medline doi:10.1073/pnas.1203849109

9. R. J. Parkes, G. Webster, B. A. Cragg, A. J. Weightman, C. J. Newberry, T. G. Ferdelman, J. Kallmeyer, B. B. Jørgensen, I. W. Aiello, J. C. Fry, Deep sub- 
seafloor prokaryotes stimulated at interfaces over geological time. Nature 436, 390-394 (2005). Medline doi:10.1038/nature03796

10. B. B. Jørgensen, A. Boetius, Feast and famine-microbial life in the deep-sea bed. Nat. Rev. Microbiol. 5, 770-781 (2007). Medline doi: $10.1038 / \mathrm{nrmicro} 1745$

11. T. M. Hoehler, B. B. Jørgensen, Microbial life under extreme energy limitation. Nat. Rev. Microbiol. 11, 83-94 (2013). Medline doi:10.1038/nrmicro2939

12. See supplementary materials on Science Online.

13. G. C. Feldman, C. R. McClain, Ocean Color Web, AquaMODros. Inf. Serv., N. Kuring, S. W. Bailey, Eds. (NASA Goddard Space Flight Center, 2013); http://oceancolor.gsfc.nasa.gov/cgi/13

14. S. Levitus, T. P. Boyer, World Ocean Atlas 1994: Volume 4: Temperature. NOAA Atlas NESDros. Inf. Serv. 4. (U.S. Government Printing Office, Washington, DC, (1994).

15. D. E. Canfield, E. Kristensen, B. Thamdrup, Aquatic Geomicrobiology (Academic Press, Amsterdam, 2005).

16. D. Fischer, J. M. Mogollón, M. Strasser, T. Pape, G. Bohrmann, N. Fekete, V. Spiess, S. Kasten, Subduction zone earthquake as potential trigger of submarine hydrocarbon seepage. Nat. Geosci. 6, 647-651 (2013). doi:10.1038/ngeo1886

17. K. O. Emery, Relict sediments on continental shelves of the world. AAPG Bull. 52, 445-464 (1968).

18. J. M. Mogollón, A. W. Dale, J. B. Jensen, M. Schlüter, P. Regnier, A method for the calculation of anaerobic oxidation of methane rates across regional scales: An example from the Belt Seas and The Sound (North Sea-Baltic Sea transition). Geo-Mar. Lett. 33, 299-310 (2013). doi:10.1007/s00367-0130329-z

19. J. M. Mogollón, A. W. Dale, H. Fossing, P. Regnier, Timescales for the development of methanogenesis and free gas layers in recently-deposited sediments of Arkona Basin (Baltic Sea). Biogeosciences 9, 1915-1933 (2012). doi:10.5194/bg-9-1915-2012

20. A. W. Dale, P. Regnier, P. Van Cappellen, H. Fossing, J. B. Jensen, B. B. Jorgensen, Remote quantification of methane fluxes in gassy marine sediments through seismic survey. Geology 37, 235-238 (2009). doi: $10.1130 / \mathrm{G} 25323 \mathrm{~A} .1$

21. G. A. Knauer, "Productivity and new production of the oceanic system," in Interactions of C, N, P and S Biogeochemical Cycles and Global Change, R. Wollast, F.T. Mackenzie, L. Chou, Eds. (Springer, Berlin, NATO ASI Series I 4, 211-231, 1993)

22. K. Sahm, B. J. MacGregor, B. B. Jørgensen, D. A. Stahl, Sulphate reduction and vertical distribution of sulphate-reducing bacteria quantified by rRNA slot-blot hybridization in a coastal marine sediment. Environ. Microbiol. 1, 65-74 (1999). Medline doi:10.1046/j.1462-2920.1999.00007.x

23. K. Ravenschlag, K. Sahm, C. Knoblauch, B. B. Jørgensen, R. Amann, Community structure, cellular rRNA content, and activity of sulfate-reducing bacteria in marine arctic sediments. Appl. Environ. Microbiol. 66, 3592-3602 (2000). Medline doi:10.1128/AEM.66.8.3592-3602.2000

24. J. Leloup, A. Loy, N. J. Knab, C. Borowski, M. Wagner, B. B. Jørgensen, Diversity and abundance of sulfate-reducing microorganisms in the sulfate and methane zones of a marine sediment, Black Sea. Environ. Microbiol. 9, 131-142 (2007). Medline doi:10.1111/j.1462-2920.2006.01122.x

25. J. Leloup, H. Fossing, K. Kohls, L. Holmkvist, C. Borowski, B. B. Jørgensen, Sulfate-reducing bacteria in marine sediment (Aarhus Bay, Denmark): Abundance and diversity related to geochemical zonation. Environ. Microbiol. 11, 1278-1291 (2009). Medline doi:10.1111/j.14622920.2008.01855.x

26. L. Holmkvist, T. G. Ferdelman, B. B. Jørgensen, A cryptic sulfur cycle driven by iron in the methane zone of marine sediment (Aarhus Bay, Denmark). Geochim. Cosmochim. Acta 75, 3581-3599 (2011). doi:10.1016/j.gca.2011.03.033

27. V. B. Heuer, J. W. Pohlman, M. E. Torres, M. Elvert, K.-U. Hinrichs, The stable carbon isotope biogeochemistry of acetate and other dissolved carbon species in deep subseafloor sediments at the northern Cascadia Margin. Geochim. Cosmochim. Acta 73, 3323-3336 (2009). doi:10.1016/j.gca.2009.03.001

28. S. L. D'Hondt et al., Proc. ODP, Init. Repts., 201 (Ocean Drilling Program, College Station, TX, 2003).

29. Y.-S. Lin, V. B. Heuer, T. Goldhammer, M. Y. Kellermann, M. Zabel, K.-U.
Hinrichs, Towards constraining $\mathrm{H}_{2}$ concentration in subseafloor sediment: A proposal for combined analysis by two distinct approaches. Geochim. Cosmochim. Acta 77, 186-201 (2012). doi:10.1016/i.gca.2011.11.008

30. R. Mithal, D. G. Becker, "The Janus Database: Providing worldwide access to ODP and IODP data." in New Techniques in Sediment Core Analysis, R. G. Rothwell, Ed. (Geological Society of London, London, 2006), vol. 267, pp. 253-259.

31. National Geophysical Data Center, National Oceanic and Atmospheric Administration, ETOPO2v2 Global Gridded 2-minute Database, U.S. Dept. of Commerce, www.ngdc.noaa.gov/mgg/global/etopo2.html.

32. G. Laske, G. Masters, A global digital map of sediment thickness. Eos Trans. $A G U$ 78, F483 (1997).

33. P. Wessel, W. H. F. Smith, a global self-consistent, hierarchical, highresolution shoreline database. J. Geophys. Res. 101, 8741-8743 (1996). doi:10.1029/96JB00104

34. R. D. M. Müller, C. Sdrolias, C. Gaina, W. R. Roest, Age, spreading rates, and spreading asymmetry of the world's ocean crust. Geochem. Geophys. Geosyst. 9, Q04006 (2008). doi:10.1029/2007GC001743

35. B. B. Boudreau, Diagenetic Models and Their Implementations (Springer, 1997).

36. T. J. Müller, "Determination of salinity." in Methods of Seawater Analysis, K. Grasshoff, K. Kremling, M. Ehrhardt, Eds. (Wiley, Weinheim, Germany, 1999), pp. 41-74.

37. N. B. Weston, W. P. Porubsky, V. A. Samarkin, M. Erickson, S. E. Macavoy, S. B. Joye, Porewater stoichiometry of terminal metabolic products, sulfate, and dissolved organic carbon and nitrogen in estuarine intertidal creek-bank sediments. Biogeochemistry 77, 375-408 (2006). doi:10.1007/s10533-005$1640-1$

38. P. J. Müller, E. Suess, Productivity, sedimentation rate, and sedimentary organic matter in the oceans-I. Organic carbon preservation. Deep-Sea Res. 26A, 1347-1362 (1979). doi:10.1016/0198-0149(79)90003-7

39. J. Milucka, T. G. Ferdelman, L. Polerecky, D. Franzke, G. Wegener, M. Schmid, I. Lieberwirth, M. Wagner, F. Widdel, M. M. Kuypers, Zero-valent sulphur is a key intermediate in marine methane oxidation. Nature 491, 541546 (2012). Medline doi:10.1038/nature 11656

40. C. Pallud, P. Van Cappellen, Kinetics of microbial sulfate reduction in estuarine sediments. Geochim. Cosmochim. Acta 70, 1148-1162 (2006). doi:10.1016/j.gca.2005.11.002

41. S. Contreras, P. Meister, B. Liu, X. Prieto-Mollar, K. U. Hinrichs, A. Khalili, T. G. Ferdelman, M. M. Kuypers, B. B. Jørgensen, Cyclic 100-ka (glacialinterglacial) migration of subseafloor redox zonation on the Peruvian shelf. Proc. Natl. Acad. Sci. U.S.A. 110, 18098-18103 (2013). Medline doi:10.1073/pnas. 1305981110

42. S. Arndt, J.-H. Brumsack, K. W. Wirtz, Cretaceous black shales as active bioreactors: A biogeochemical model for the deep biosphere encountered during ODP Leg 207 (Demerara Rise). Geochim. Cosmochim. Acta 77, 186201 (2006).

43. D. E. Canfield, Sulfate reduction and oxic respiration in marine sediments: Implications for organic carbon preservation in euxinic environments. DeepSea Res. 36, 121-138 (1989). Medline doi:10.1016/0198-0149(89)90022-8

44. L. A. Levin, Oxygen minimum zone benthos: Adaptation and community response to hypoxia. Oceanogr. Mar. Biol. 41, 1-45 (2003).

Acknowledgments: All data used in this study are publically available via Janus and Pangea (www.pangea.de). We thank DSDP/ODP/IODP, Janus, and Pangea for compiling and providing these datasets. We thank A. Boetius, J. J. Middelburg, and S. Joye for helpful comments during the development of this work. Primary support for this work was graciously provided by the Research Center/Cluster of Excellence "The Ocean in the Earth System" (MARUM) funded by the Deutsche Forschungsgemeinschaft (DFG) in the framework of a Postdoctoral Fellowship, while additional funding was provided by the European Research Council under the European Union's Seventh Framework Programme-"Ideas" Specific Programme, ERC grant agreement no. 247153, the Helmholtz Association (AWI Bremerhaven), and by Utrecht University through its strategic theme Sustainability, sub-theme Water, Climate \& Ecosystems.

\section{Supplementary Materials} www.sciencemag.org/cgi/content/full/science.1249213/DC1 Materials and Methods 
Supplementary Text

Figs. S1 to S6

Table $\mathrm{S} 1$ to $\mathrm{S} 4$

References (30-44)

2 December 2013; accepted 29 April 2014

Published online 8 May 2014

$10.1126 /$ science. 1249213 


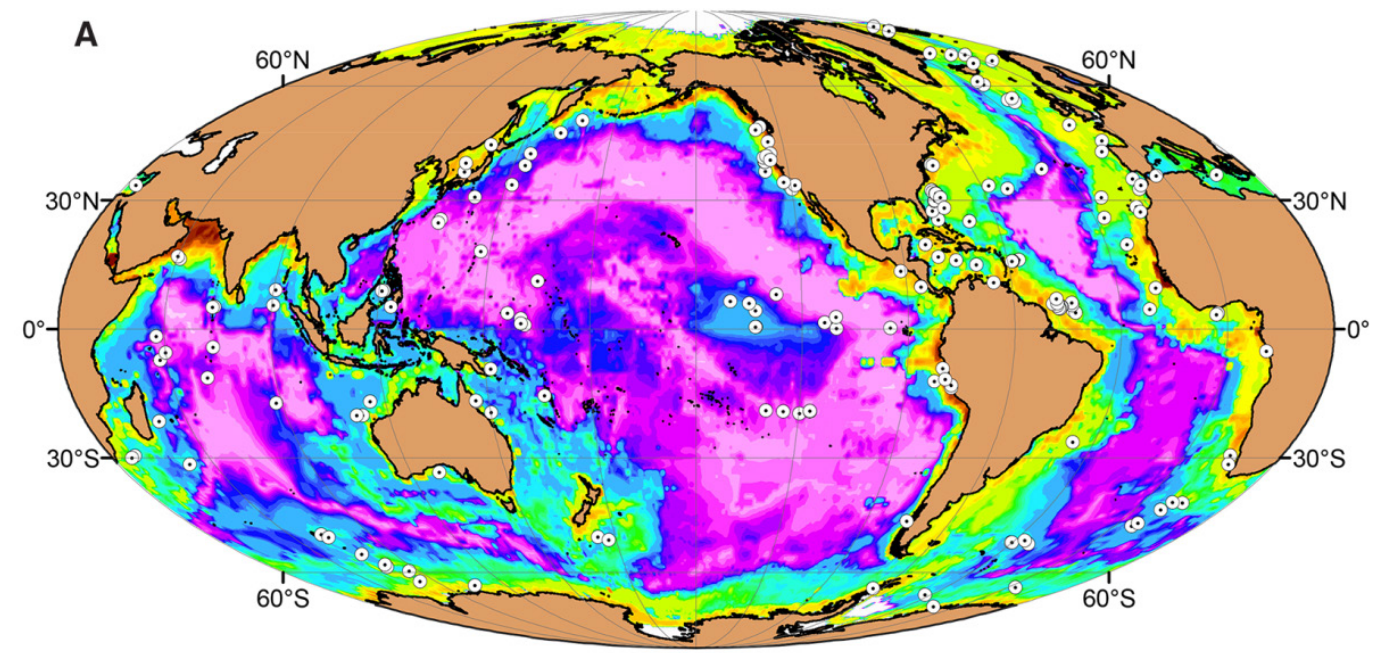

Depth-integrated sulfate reduction rates $\left(\mathrm{mmol} \mathrm{cm}^{-2} \mathrm{y}^{-1}\right)$
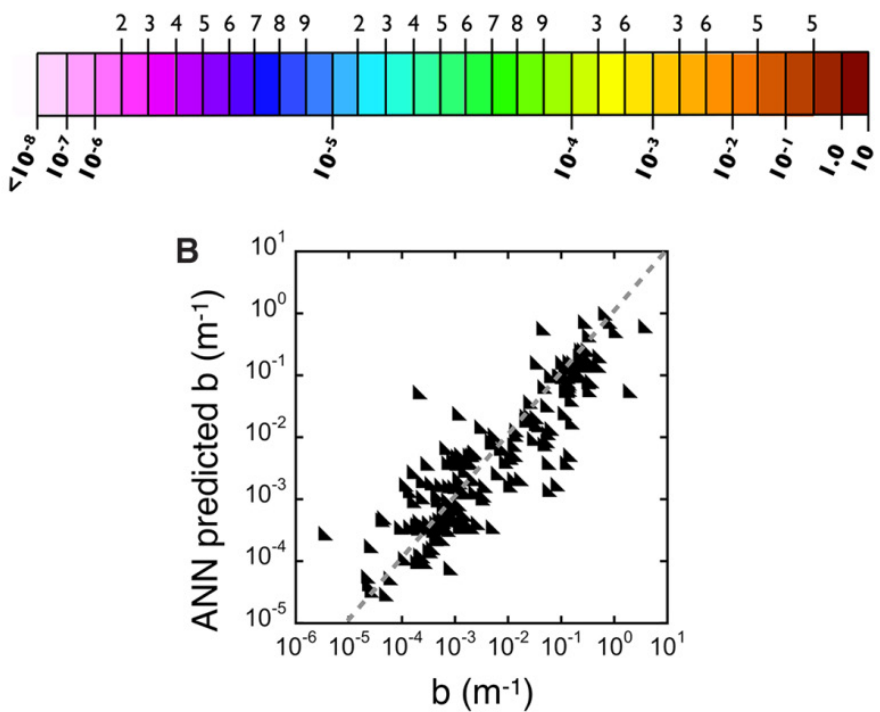

Fig. 1. Global sulfate reduction rates in marine sediments. (A) Global distribution of depth integrated sulfate reduction rates $\left(\mathrm{mmol} \mathrm{cm} \mathrm{cm}^{-2} \mathrm{y}^{-1}\right.$ ) based on predictions of the exponential depth-decay constant, $b$, from an artificial neural network (ANN) in a $1^{\circ} \times 1^{\circ}$ resolution. Black point symbols represent 199 DSDP/ODP/IODP sites with sulfate profiles described by an exponential fit ultimately used to train, validate, and test the ANN. (B) The correspondence of predicted $b$ from the ANN and the actual fit values of $b$ for all profiles $(R=0.88)$. 


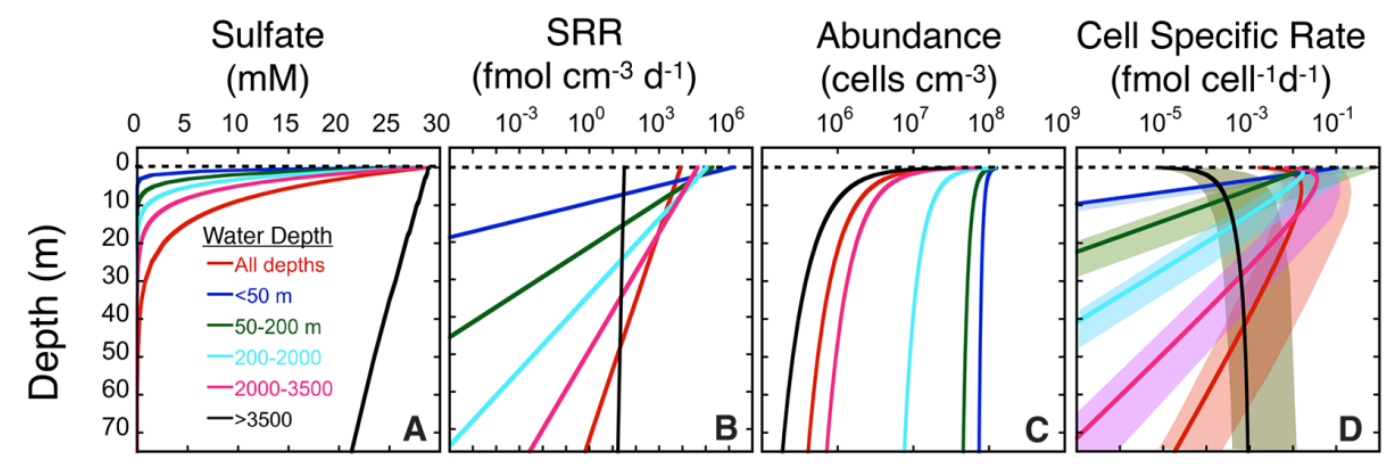

Fig. 2. Subsurface profiles of area-weighted parameters in various oceanic depth zones. (A) sulfate profiles $(\mathrm{mM})$, (B) sulfate reduction rates (fmol $\mathrm{cm}^{-3} \mathrm{~d}^{-1}$ ), (C) cellular abundances (cells $\mathrm{cm}^{-3}$ ) (8), (D) cell specific rates (fmol cell ${ }^{-1} \mathrm{~d}^{-1}$ ) with bold lines representing a $10 \%$ sulfate reducing microorganism contribution to the total population while the shaded region for each line represents a $1 \%$ and $30 \%$ contribution of sulfate reducer to the total population. 
Table 1. Weighted average depth-integrated sulfate reduction rate for different water depths. The total area covered here is around $349 \times 10^{6} \mathrm{~km}^{2}$ or about $97 \%$ of the total ocean.

\begin{tabular}{|c|c|c|c|c|}
\hline Region & $\begin{array}{c}\text { Weighted average } \\
\text { depth-integrated } \\
\text { SRR } \\
\begin{array}{c}\left(\begin{array}{ccc}\mathbf{1 0} & \mathrm{mmol} \mathrm{cm}^{-2} \\
\mathrm{y}^{-1}\end{array}\right) \\
\end{array}\end{array}$ & $\begin{array}{c}\text { Total SRR } \\
\left(\operatorname{Tmmol~y}^{-1}\right)\end{array}$ & $\begin{array}{c}\% \text { Total SRR } \\
\left(\operatorname{Trmol~y}^{-1}\right)\end{array}$ & $\operatorname{Area}\left(x 10^{6} \mathrm{~km}^{2}\right)$ \\
\hline Inner shelf $(0-50 \mathrm{~m})$ & 39.3 & 2.9 & 26 & 7.6 \\
\hline Outer shelf $(50-200 \mathrm{~m})$ & 16.2 & 2.1 & 19 & 13 \\
\hline Slope $(200-2000 \mathrm{~m})$ & 11.2 & 3.3 & 29 & 29 \\
\hline Rise $(2000-3500 \mathrm{~m})$ & 4.4 & 2.7 & 24 & 63 \\
\hline Abyss $(>3500 \mathrm{~m})$ & 0.09 & 0.2 & 2 & 237 \\
\hline Global total & 3.2 & 11.3 & 100 & 349 \\
\hline
\end{tabular}

Table 2. Global analysis of sulfate reduction rates with respect to published carbon fluxes to the sea floor for various water depth environments. NR = concentration not reached. The global values in bold represent totals, whereas italics represent area weighted averages.

\begin{tabular}{|c|c|c|c|c|c|c|}
\hline Region & $\begin{array}{c}\text { Depth } \\
\text { to } 0.1 \mathrm{mM} \\
\text { sulfate }(\mathrm{m})\end{array}$ & $\begin{array}{c}\text { \% Prokary- } \\
\text { otes above } 0.1 \\
\text { mM sulfate }\end{array}$ & $\begin{array}{c}\text { Carbon } \\
\text { flux (3) } \\
\left(\operatorname{Tmmol~y}^{-1}\right)\end{array}$ & $\begin{array}{l}\text { \% Carbon re- } \\
\text { mineralized by } \\
\text { SR }\end{array}$ & $\begin{array}{c}\text { Carbon } \\
\text { flux (4) } \\
\left(\operatorname{Tmol~y}^{-1}\right)\end{array}$ & $\begin{array}{c}\text { \% Carbon re- } \\
\text { mineralized by } \\
\text { SR }\end{array}$ \\
\hline $\begin{array}{l}\text { Inner shelf } \\
(0-50 \mathrm{~m})\end{array}$ & 3.8 & 0.25 & \multirow{2}{*}{63} & \multirow{2}{*}{16} & 92 & 6.3 \\
\hline $\begin{array}{l}\text { Outer shelf } \\
(50-200 \mathrm{~m})\end{array}$ & 9.9 & 0.86 & & & 43 & 9.7 \\
\hline $\begin{array}{l}\text { Slope (200- } \\
2000 \mathrm{~m})\end{array}$ & 17 & 5.6 & & \multirow{3}{*}{74} & 30 & 22 \\
\hline $\begin{array}{l}\text { Rise (2000- } \\
3500 \mathrm{~m})\end{array}$ & 26 & 31 & 17 & & 26 & \multirow[t]{2}{*}{22} \\
\hline $\begin{array}{l}\text { Abyss } \\
(>3500 \mathrm{~m})\end{array}$ & NR & 100 & & & & \\
\hline Global total & 47 & 45 & 80 & 28 & 191 & 12 \\
\hline
\end{tabular}

